\title{
ANALISIS KEPATUHAN PERAWAT TERHADAP PENCEGAHAN DAN PENGENDALIAN INFEKSI DI RUMAH SAKIT MUHAMMADIYAH PALEMBANG
}

\author{
Romiko \\ Program Studi IImu Keperawatan, STIKes Muhammadiyah Palembang \\ Email: ns.romiko@gmail.com
}

\begin{abstract}
ABSTRAK
Latar Belakang: Infeksi nosokomial sangat berpengaruh terhadap kondisi kesehatan pasien secara menyeluruh dan dapat meningkatkan morbiditas serta mortalitas. Kejadian infeksi nosokomial di Rumah Sakit Muhammadiyah Palembang masih banyak ditemukan, kepatuhan perawat dalam mencegah dan mengendalikan infeksi merupakan faktor yang sangat penting dalam pencegahan terjadinya infeksi nosokomial. Tujuan Penelitian: untuk menganalisis kepatuhan perawat terhadap pencegahan dan pengendalian infeksi di Rumah Sakit Muhammadiyah Palembang serta determinanya. Metode Penelitian: Jenis penelitian ini adalah penelitian kualitatif dengan pendekatan interaktif. Sumber informan sebanyak tiga orang perawat pelaksana, tiga orang kepala ruang, dan satu orang perawat PPIRS. Pengumpulan data melalui wawancara mendalam, studi dokumentasi dan observasi. Analisis diuraikan dalam bentuk deskriptif dan naratif. Hasil: hasil penelitian menunjukkan bahwa delapan kemampuan perawat dalam melakukan pencegahan dan pengendalian infeksi nosokomial belum sesuai dengan aturan menurut WHO. Determinan dalam pelaksanaannya antara lain pendidikan perawat, lama bekerja, tempat tugas, kebutuhan SDM dan alat pendukung, kenyamanan terhadap fasilitas pendukung, pelatihan/sosialisasi, monitoring dan evaluasi serta koordinasi antar unit. Kesimpulan: kemampuan perawat dalam pencegahan dan pengendalian infeksi nosokomial di RSMP masih belum optimal dan banyak hambatan dalam pelaksanaannya. Manajemen rumah sakit dan Tim PPI disarankan melakukan penyegaran kembali materi tentang PPI dan melakukan monitoring terhadap penerapan SPO PPI.
\end{abstract}

Kata Kunci: Kepatuhan, Perawat, PPI, Infeksi Nosokomial

\section{ABSTRACT}

Background: Nosocomial infection is very influential on a patient's overall health condition and can increase morbidity and mortality. The incidence of nosocomial infections in Muhammadiyah Hospital Palembang is still widely found, nurses' adherence in preventing and controlling infections is a very important factor in preventing nosocomial infections. Research Objectives: to analyze nurses' adherence to infection prevention and control at Palembang Muhammadiyah Hospital and its determinants. Research Methods: This type of research is a qualitative research with an interactive approach. Informants were as many as three associate nurses, three head nurses, and one Infection Prevention Control Nurse (IPCN). Data collection through in-depth interviews, documentation studies and observations. The analysis is described in descriptive and narrative form. Results: The results showed that eight nurses' ability to prevent and control nosocomial infections was not in accordance with WHO regulations. Determinants in its implementation include nurse education, length of work, place of assignment, human resource needs and supporting tools, comfort of supporting facilities, training, monitoring and evaluation as well as coordination among units. Conclusion: the ability of nurses in the prevention and control of nosocomial infections in RSMP is still not optimal and there are many obstacles in their implementation. Hospital management and the IPC Team are advised to re-refresh the material on IPC and to monitor the implementation of IPC standard operational procedures.

Keyword: Compliance, Nurse, IPC, Nosocomial Infection 


\section{PENDAHULUAN}

Rumah Sakit sebagai salah satu fasilitas pelayanan kesehatan memiliki peran yang sangat strategis dalam upaya mempercepat peningkatan derajat kesehatan masyarakat yang menyelenggarakan pelayanan kesehatan perorangan secara paripurna (meliputi promotif, preventif, kuratif dan rehabilitatif) dengan menyediakan pelayanan rawat inap, rawat jalan, dan gawat darurat (UU RI No. 44 Tahun 2009).

Masyarakat yang menerima pelayanan kesehatan, tenaga kesehatan dan pengunjung di rumah sakit dihadapkan pada risiko terjadinya infeksi atau infeksi nosokomial atau yang sekarang dikenal dengan istilah Health Care Associated Infections (HAls) yaitu infeksi yang diperoleh dari rumah sakit, baik karena pelayanan perawatan atau dari pengunjung yang berkunjung ke rumah sakit (PMK, 2017).

Di negara yang sedang berkembang maupun negara maju, angka kejadian infeksi nosokomial di masih sangat tinggi. Berdasarkan hasil literature review yang dilakukan oleh World Health Organization (WHO) dari beberapa hasil penelitian yang dipublikasi sejak tahun 1995-2008, diperoleh bahwa data prevalensi infeksi nosokomial di negara maju berkisar di antara $5,1 \%$ sampai $11,6 \%$, sedangkan di negara yang sedang berkembang berkisar diantara 5-19\%. (WHO, 2010). Centers of Disease Control and Prevention (CDC) pada tahun 2011 memperkirakan setidaknya terdapat 722.000 pasien menderita infeksi nosokomial di Amerika Serikat. Sekitar 75.000 pasien diantaranya meninggal dunia selama perawatan di rumah sakit. Selain itu, badan kesehatan dunia WHO memperkirakan bahwa dalam waktu tertentu 1.4 juta atau $10 \%$ penduduk dunia akan terkena infeksi yang menyebabkan kematian setiap hari di dunia (Depkes, 2008).
Di negara Indonesia sendiri, infeksi masih merupakan penyebab utama kematian dan kesakitan di rumah sakit dan fasilitas pelayanan kesehatan lainnya (Herpan, 2012). Menurut Nugraheni, dkk. (2012), infeksi nosokomial pada 10 Rumah Sakit Umum (RSU) pendidikan di Indonesia cukup tinggi yaitu diantara 6$16 \%$ dengan rata-rata $9,8 \%$ pada tahun 2010. Infeksi nosokomial yang paling umum terjadi adalah Infeksi Luka Operasi (ILO). Hasil penelitian terdahulu menunjukkan bahwa angka kejadian ILO pada rumah sakit di Indonesia bervariasi antara $2-18 \%$ dari keseluruhan prosedur pembedahan.

Hasil survey point prevalensi dari 11 rumah sakit di DKI Jakarta yang dilakukan oleh Perdalin Jaya dan Rumah Sakit Penyakit Infeksi Prof. Dr. Sulianti Saroso Jakarta pada tahun 2003 didapatkan angka infeksi nosokomial untuk ILO (Infeksi Luka Operasi) 18,9\%, ISK (Infeksi Saluan Kemih) 15,1\%, IADP (Infeksi Aliran Darah Primer) 26,4\%, pneumonia 24,5\% dan infeksi saluan napas lain $15,1 \%$ serta infeksi lain 32,1\% (Depkes RI 2008).

Secara prinsip, kejadian HAls sebenarnya dapat dicegah bila fasilitas pelayanan kesehatan secara konsisten melaksanakan program Pencegahan dan Pengendalian Infeksi (PPI). Pencegahan dan Pengendalian Infeksi merupakan upaya untuk memastikan perlindungan kepada setiap orang terhadap kemungkinan tertular infeksi dari sumber masyarakat umum dan disaat menerima pelayanan kesehatan pada berbagai fasilitas kesehatan (PMK, 2017).

Sebagai salah satu rumah sakit swasta di Kota Palembang, kejadian infeksi nosokomial di Rumah Sakit Muhammadiyah Palembang (RSMP) masih banyak terjadi, terutama di ruang perawatan yang sangat rentan terjadinya infeksi nosokomial seperti di ruang penyakit dalam, bedah, dan anak. Dalam 
rangka menurunkan angka kejadian infeksi nosokomial di RSMP sejak awal tahun 2014, rumah sakit telah menerapkan berbagai kebijakan terkait Pencegahan dan Pengendalian Infeksi (PPI) seperti pembatasan jumlah pengunjung, membuat peraturan jam berkunjung, dan mengedukasi serta mempromosikan cuci tangan kepada keluarga pasien untuk menghindari transmisi penularan infeksi dari pengunjung (RSMP, 2018).

Selain itu, juga dilakukan sterilisasi alat kesehatan oleh staf terlatih, swab ruangan berisiko tinggi seperti kamar operasi dan kamar perawatan intensif secara berkala guna memperoleh gambaran peta kuman, melengkapi fasilitas terkait PPI seperti Hand Rub di setiap ruangan dan mengganti disinfektan alkohol $70 \%$ botolan dengan alcohol swab yang lebih steril serta menyediakan APD untuk mencegah transmisi infeksi. Namun, berbagai upaya diatas tidak berhasil menurunkan infeksi nosokomial secara bermakna.

Menurut Darmadi (2008), tenaga keperawatan sebagai petugas yang selalu kontak dengan penderita (selama 24 jam) merupakan pelaksana terdepan dalam upaya pencegahan dan pengendalian infeksi nosokomial. Kurangnya perhatian perawat akan teknik steril saat melakukan tindakan, lamanya proses keperawatan, standar pelayanan yang kurang optimal serta padatnya penderita dalam ruangan yang dirawat oleh perawat mempengaruhi terjadinya infeksi nosokomial. Pristiwani (2013) juga menyatakan bahwa infeksi nosokomial berkaitan langsung dengan dengan peran perawat dalam pemberian asuhan keperawatan.

Berdasarkan hasil studi awal di RSMP, ditemukannya angka infeksi nosokomial sebagaimana diuraikan di atas, kemungkinan disebabkan oleh masih rendahnya kemampuan perawat dalam menerapkan program PPI. Dari hasil wawancara dengan ketua Tim PPI diketahui bahwa sampai saat ini masih banyak perawat pelaksana yang kurang menjaga kebersihan ruangan, kadang tidak memakai APD, belum paham prinsip aseptik, sterilisasi alat dan sistem isolasi. Beberapa perawat baru bahkan belum pernah mengikuti pelatihan terkait PPI sebelumnya. Selain itu, dari data self assessment (kajian mandiri) yang dilakukan Komite PPI, diketahui bahwa kepatuhan perawat dalam melaksanakan Standar Prosedur Operasional (SPO) terkait PPI secara baik dan benar masih dibawah $80 \%$.

Berdasarkan latarbelakang diatas peneliti tertarik untuk meneliti dan menganalisis kepatuhan perawat terhadap Pencegahan dan Pengendalian Infeksi di Rumah Sakit Muhammadiyah Palembang.

\section{METODE PENELITIAN}

Jenis penelitian ini adalah penelitian kualitatif dengan pendekatan interaktif. Sumber informan sebanyak tiga orang perawat pelaksana, tiga orang kepala ruang dan satu orang Infection Prevention Control Nurse (IPCN). Untuk mendapat data yang tepat maka perlu ditentukan sumber informasi (informan) yang memiliki kompetensi dan sesuai dengan kebutuhan data (Sugiyono, 2015). Pengumpulan data melalui wawancara mendalam, studi dokumentasi dan observasi. Analisis diuraikan dalam bentuk deskriptif dan naratif melalui langkah pengumpulan data, reduksi data, penyajian data dan penarikan kesimpulan. Lokasi penelitian di ruang rawat inap (Pentakit Dalam, Bedah, Anak) Rumah Sakit Muhammadiyah Palembang dan dilakukan pada bulan Juni sampai dengan Agutus 2018. 


\section{HASIL PENELITIAN}

\section{a. Karakteristik Informan}

Hasil penelitian yang dilakukan di RSMP diketahui karakteristik informan berdasarkan umur sebanyak 2 orang informan berada pada rentang usia 25-32 tahun dan sebanyak lima orang berada pada rentang usia 38-44 tahun. Berdasarkan jenis kelamin lebih banyak perempuan yaitu enam orang dan selebihnya satu orang laki-laki. Berdasarkan pendidikan lebih banyak S1 Keperawatan selebihnya Ners dan D3 Keperawatan. Berdasarkan lama bertugas dua orang pada rentang waktu 3-10 tahun dan lima orang pada rentang waktu 15-19 tahun. Berdasarkan keikutsertaan pelatihan, semua informan sudah pernah mengikuti pelatihan.

\section{b. Kepatuhan Perawat dalam Pencegahan dan Pengendalian Infeksi Nosokomial di RSMP}

\section{Menjaga Kebersihan dan kerapihan Rumah Sakit}

Berdasarkan hasil wawancara dengan 6 perawat dari tiga ruang rawat inap di RSMP, diketahui bahwa dalam menjaga kebersihan untuk pencegahan dan pengendalian infeksi nosokomial, kepatuhan 4 dari 6 perawat $(66,67 \%)$ di RSMP telah tergolong baik. Namun, masih terdapat dua perawat yang belum mampu menjalankan perannya dalam menjaga kebersihan rumah sakit. Hal ini terlihat dari pernyataan berikut:

"Dalam menjaga kebersihan RS, kami hanya membuang sampah pada tempatnya..Itu aja sih..dan sudah ada CS yang membantu..." (Informan 1).

\section{"Limbah yang terkena darah kotoran pasien, air liur pasien dimasukkan ke ember hitam khusus untuk limbah infeksius..." (Informan 2).}

\section{Pelaksanaan Cuci Tangan}

Berdasarkan hasil wawancara dengan 6 perawat dari 3 ruang rawat inap di RSMP tentang cara dan tahapan dalam melakukan cuci tangan untuk pencegahan dan pengendalian infeksi nosokomial, diperoleh informasi bahwa kepatuhan 4 dari 6 perawat $(66,67 \%)$ dalam pelaksanaan cuci tangan sudah tergolong baik, namun terdapat dua perawat yang belum mampu melaksanakan cuci tangan dengan baik dan benar seperti penyataan berikut:

"Saya masih sering lupa tahapan cuci tangan walaupun selalu diingatkan saat overan di nurse station, saya sering lupa..." (Informan 5).

"Kalau pake handrub tangan dicuci selama 20-30 menit.. eh detik , maksudnya.. kadang- kadang lupanya gini.. kalau sudah dipanggil sus.. cairan infusnya habis.. nah disana sering kelupaan cuci tangan karena uda mau cepat..." (Informan 6)

\section{Menggunakan Alat Pelindung Diri (APD)}

Berdasarkan hasil wawancara dengan 6 perawat dari 3 ruang rawat inap di RSMP tentang menggunakan alat pelindung untuk pencegahan dan pengendalian infeksi nosokomial mencakup cara menggunakan dan tahapan menggunakannya, diperoleh informasi bahwa kepatuhan 3 dari 6 perawat $(50 \%)$ dalam menggunakan APD telah tergolong baik. Namun, beberapa perawat lainnya kurang patuh menggunakan APD secara baik dan benar seperti pernyataan berikut:

"Lupa pake handscoen karena kondisi tiba-tiba seperti dipanggil pas infus pasien terlepas... jadi darah pasiennya kan nyocor.. mau balik lagi ambil handscoen kadang-kadang gak sempat.. kan kasihan juga pasiennya.. yang terpaksa kami pegang dulu.. nanti baru 
kami cepat- cepat cuci tangan..." (Informan 4).

"Handscoen dipakai saat melakukan injeksi dan mengganti perban tapi ga selalu dipake soalnya kan boros..." (Informan 1).

"APD dipakai untuk satu orang satu pasien. saat melakukan tindakan, infus, mengganti pampers, hanya itu.. Klo untuk menginjeksi tidak ganti sarung tangan karena biar menghemat..." (Informan 6).

\section{Menggunakan Teknik Aseptik}

Berdasarkan hasil wawancara dengan 6 perawat dari 3 ruang rawat inap RSMP tentang menggunakan teknik aseptik mencakup melakukan teknik dan tahapan pelaksanaannya, diperoleh informasi bahwa kepatuhan 4 dari 6 (66,67\%) perawat di RSMP masih kurang baik. Beberapa matriks jawaban diantaranya adalah:

"Untuk perawatan tali pusat biasanya di lakukan setelah bayi dimandikan.. caranya pertama pakai handscoen lalu tali pusat di bungkus dengan kasa steril.. cuman terkadang lupa untuk cuci tangan..." (Informan 3).

"Cuman kami tidak menggunakan handscoen steril (untuk menjahit luka).. karena menurut saya luka itu kan waktu datang kotor jadi yah gak apa- apa kalau tidak pake yang non steril..." (Informan 1).

"Pasang kateter digunakan sarung tangan biasa karena tak ada sarung tangan steril,didesinfeksikan dengan air dari dalam ke luar..." (Informan 2).

\section{Melapor kepada Dokter Jika Ada Tanda dan Gejala Infeksi}

Berdasarkan

hasil wawancara

dengan 6 perawat dari 3 ruang rawat inap tentang melapor kepada dokter jika ada tanda dan gejala infeksi mencakup cara dan tahapan dalam pelaksanaannya, diperoleh informasi bahwa dalam melapor kepada dokter jika ada tanda dan gejala infeksi, kepatuhan 5 dari 6 perawat $(83,33 \%)$ di RSMP tergolong baik. Adapun beberapa pernyataannya adalah:

"Bila dijumpai tanda dan gejala infeksi nosokomial, biasanya tanda-tanda infeksi itu kemerahan, bengkak, kadang berpus dan lain-lain.. biasa bila ada tanda sepeti itu kami lapor dan minta dokter memeriksa..." (Informan 3).

"Jika ada flebitis dengan tanda ada luka, merah, panas dan nyeri, saya melapor ke karu dulu.. bila izin maka saya ganti, bisa saya atau karu yang melapor ke dokternya. (Informan 2).

"Kalo via phone sebelumnya kita perkenalkan diri.. baru kita ceritakan kondisi pasien sesuai hasil pemeriksaan, vital sign nya dan lainlain.. baru kita tanyakan apa rekomendasinya.. baru kita catat.. untuk memastikannya kita baca ulang kembali.. misalnya obat yang kita tambahankan ini ya dok, dosisnya segini.. baru kita ucapkan selamat siang dan tutup teleponnya..." (Informan 7).

Akan tetapi, terdapat 1 informan yang belum mengetahui dengan benar prosedur di atas, seperti pada pernyataan berikut: "Cara laporkan dan komunikasi bila ada infeksi. Biasanya ya melapor ke dokter operator sesuai tanda infeksi yang muncul... nanti paling disuruh naikkan antibiotic..." (Informan 5). 


\section{Melakukan Isolasi terhadap Pasien dengan Penyakit Menular}

Berdasarkan hasil wawancara dengan 6 perawat dari 3 ruang rawat inap tentang melakukan isolasi terhadap pasien dengan penyakit menular bagaimana melakukan isolasi dan bagaimana tahapan yang dilakukan, diperoleh informasi kemampuan 3 dari 6 (50,00\%) perawat di RSMP masih kurang baik sebagaimana terlihat dari pada beberapa contoh matrik berikut ini:

"Biasanya pasien menular kami rawat di kamar isolasi, kek pasien TB.. DM dengan ganggren, hepatitis.. ehm.. yang menular lah pokoknya..." (Informan 1).

"Pasien yang butuh isolasi misalnya pasien HIV AIDS, cacar, dan TB paru dipisahkan dan dirawat di ruangan khusus..." (Informan 4).

"Setau saya yang perlu diisolasi dan dirawat terpisah itu pasien TB paru, pasien DM yang ada ganggren nya karena kan terganggu karena baunya, HIV.. terus pasien-pasien yang menular lainnya..." (Informan 5).

Hal ini dipertegas oleh pernyataan berikut:

"Kamar yang terutama.. itu selalu penuh..." (Informan 4).

"Karena ruangan isolasi kita selalu penuh, terpaksa pasien kadang dirujuk..." (Informan 3).

\section{Membatasi Paparan Pasien terhadap Infeksi yang Berasal dari Pengunjung}

Berdasarkan hasil wawancara dengan 6 perawat dari 3 instalasi di RSMP tentang membatasi paparan pasien terhadap infeksi yang berasal dari pengunjung mencakup cara membatasi paparan pasien terhadap infeksi yang berasal dari pengunjung dan tahapan yang dilakukan dalam pelaksanaannya, diperoleh informasi bahwa dalam membatasi paparan pasien terhadap infeksi yang berasal dari pengunjung, kepatuhan 4 dari 6 perawat $(66,67 \%)$ di RSMP tergolong baik, sebagaimana dirangkum pada matrik berikut ini:

"Ehm.. kalau kami batasi 2 orang pengunjung untuk 1 pasien, kalau sudah berlebih kami suruh keluar dulu.. nanti ganti-gantian.. selain itu kami berlakukan jam berkunjung, yaitu jam 10.00-11.00 dan jam 16.00-17.00..." (Informan 6).

"Yah tadi.. dibatasi pengunjungnya.. biasanya diberi edukasi jangan menyentuh alat dan menjaga jarak dari peralatan di ruangan ini agar alat steril tidak terkontaminasi..." (Informan 4).

Namun, beberapa perawat masih menganggap bahwa peran mereka dalam membatasi paparan pasien terhadap infeksi hanya sekedar membatasi jumlah pengunjung, seperti penyataan berikut: "Paling kami batasi jumlah pengunjung.. Itu aja sih..." (Informan 6).

"Kami batasi jumlah pengunjung.. biasanya kami batasi 1 pasien 1 orang pengunjung.. kalau terlalu ramai yah kami suruh keluar..." Itu saja sih.. (Informan 3).

Mempertahankan Keamanan Peralatan dan Perlengkapan Perawatan dari Penularan Infeksi Nosokomial

Berdasarkan hasil wawancara dengan 6 perawat dari 3 ruang rawat inap tentang mempertahankan keamanan peralatan dan perlengkapan perawatan dari penularan infeksi nosokomial mencakup cara dan tahapan dalam pelaksanaannya, diperoleh informasi bahwa kepatuhan 4 dari 6 perawat $(66,67 \%)$ di RSMP sudah tergolong baik dan masih terdapat perawat $(33,33 \%)$ yang kurang baik sebagaimana terlihat dari beberapa matriks di bawah ini: 
"Untuk alat yang disterilakan.. Hmm aduh apa ya.. padahal da blajar dulu.. yang itu kalau kritikal yang kena membran mukosa, non kritikal seperti stetoskop..." (Informan 5).

"Untuk alat THT seperti spatel tounge, falk serumen, nasal forsep dan lain-lain termasuk set GV hanya disterilkan 1 kali di pagi hari..." (Informan 6 ).

"Klo nebu kadang-kadang dibersihkan, Tensi yang kadang sering lupa..." (Informan 4).

\section{PEMBAHASAN}

\section{Menjaga Kebersihan Rumah Sakit}

Terdapat dua informan yang belum mengetahui perannya secara lengkap dalam menjaga kebersihan rumah sakit, kurang mengetahui proses dan tahapan pemilahan dan pengelolahan limbah, serta penanganan linen secara baik dan benar.

Padahal, berdasarkan studi dokumen rumah sakit terlihat bahwa dokumen pedoman dan SPO terkait pengelolahan limbah dan kebersihan rumah sakit sudah ada, bahkan telah tersedia di masing-masing instalasi/bagian. Dua informan yang kurang mampu tersebut bahkan sudah pernah mengikuti pelatihan terkait PPI maupun sosialisasi SPO, namun kemampuan mereka terkait menjaga kebersihan lingkungan masih belum juga maksimal. Menurut asumsi peneliti, kondisi ini terjadi karena penalaran perawat yang belum baik.

Menurut Asmadi (2008), pendidikan berpengaruh terhadap pola pikir individu, dengan kata lain pola pikir seseorang yang berpendidikan rendah akan berbeda dengan pola pikir seseorang yang berpendidikan tinggi. Pendidikan keperawatan mempunyai pengaruh besar terhadap kualitas pelayanan keperawatan, sehingga pendidikan yang tinggi dari seorang perawat akan memberi pelayanan yang optimal. Sejalan dengan hasil penelitian Saragih dan Rumapea (2010), terdapat hubungan yang bermakna antara tingkat pendidikan dan kepatuhan perawat dalam menerapkan PPI di RS Columbia Asia Medan.

Kendala lain yang dihadapi para perawat dalam menjaga kebersihan rumah sakit adalah plastik pelapis tong sampah, jerigen benda tajam, dan laken yang masih kurang. Menurut Wilma (2013), ada hubungan bermakna secara signifikan antara dukungan manajemen berupa ketersediaan sarana dan prasarana penunjang dengan pelaksanaan pencegahan infeksi nosokomial oleh perawat pelaksana. Akan tetapi, IPCN RSMP menyatakan hal ini bukan terjadi karena kurangnya dukungan manajemen. melainkan karena koordinasi antar unit yang belum berjalan dengan baik.

"Direktur sih komitmen., apapun permintaan dari PPI selalu diberikan karena itu memang kebutuhan. Tetapi kadang proses koordinasi untuk pengadaannya sedikit terkendala karena butuh waktu koordinasi satu dengan yang lainnya seperti memohon untuk ditindaklanjutin, kadang lupa memasukkan dalam anggaran biaya sehingga agak lama..." (Informan 7).

Dari pernyataan tersebut, dapat terlihat bahwa koordinasi antara bidang keperawatan, tim PPI, bagian logistik, dan bagian keuangan masih belum berjalan dengan maksimal. Akibatnya, ketika sarana dan prasarana tersebut habis terpakai sebelum waktunya maka akan membutuhkan waktu dan proses yang lama dalam pengadaannya.

\section{Pelaksanaan Cuci Tangan}

Sebagian besar informan menyatakan 
sudah memahami prosedur cuci tangan dengan handrub dan handwash dalam pencegahan dan pengendalian infeksi nosokomial. Hanya saja masih terdapat dua informan yang kadang melupakan tahapan dan durasi cuci tangan, walaupun dari hasil observasi dokumen terlihat bahwa pedoman dan SPO terkait kebersihan tangan sebenarnya telah tersedia di setiap instalasi/bagian, termasuk gambar cuci tangan sesuai WHO telah ditempelkan di setiap tempat mencuci tangan.

Menurut kepala ruangan dan IPCN, telah dilakukan responsi langsung kepada perawat pelaksana setiap harinya.

"Jika ada perawat yang belum tahu, kita beritahu agar mereka mengerti dan menerapkannya. Kita cari kendalanya dimana dan mereka diajari sampai mereka paham dan kebiasaan..."(Informan 7).

Namun, pelaksanaan cuci tangan terutama bagi perawat pelaksana belum sepenuhnya membudaya. Hal ini mungkin disebabkan karena kedua perawat pelaksana tersebut masih baru bekerja selama 1-2 tahun di rumah sakit, sehingga pengalaman mereka dalam hal akreditasi rumah sakit masih kurang.

Sejalan dengan penelitian Mathuridy (2015) juga menunjukkan bahwa terdapat hubungan yang bermakna antara lama bekerja dengan kepatuhan melakukan enam langkah lima momen cuci tangan. Disamping itu, hasil penelitian Saragih dan Rumapea (2010) yang menyatakan adanya hubungan bermakna antara lama bekerja dengan tingkat kepatuhan melakukan cuci tangan di Rumah Sakit Columbia Asia Medan.

Menurut Mulyatiningsih (2013), masa kerja biasanya dikaitkan dengan waktu mulai bekerja, dimana pengalaman kerja juga ikut menentukan sikap dan kinerja seseorang, semakin lama masa kerjanya maka kecakapan dan sikap seseorang akan lebih baik karena sudah menyesuaikan diri dengan pekerjaannya. Masa kerja yang lebih lama menunjukkan pengalaman kerja yang lebih pada seseorang dibandingkan dengan rekan kerja yang lain.

Selain lama bekerja, hambatan terbesar pelaksanaan 6 langkah dan 6 waktu cuci tangan adalah kesibukan yang dihadapi oleh masing-masing perawat akibat kurangnya SDM. Dari hasil wawancara dapat terlihat bahwa overload beban kerja perawat akibat perbandingan jumlah perawat dan pasien yang belum sesuai menjadi penyebab utama ketidakpatuhan cuci tangan. Hal ini sesuai dengan pernyataan IPCN RSMP:

"Pengetahuan uda baik tapi untuk skillnya sendiri sering saya temui tidak sesuai standar, mereka berasalan "kita tahu, hanya kami sibuk, kami tahu prinsipnya hanya kadang tidak sempat..." (Informan 7).

Adapun hambatan lain dari pelaksanaan cuci tangan pada penelitian ini adalah dari segi fasilitas cuci tangan, dimana terlihat di beberapa instalasi masih terdapat sarana-prasarana yang belum memadai.

\section{Menggunakan Alat Pelindung Diri (APD)}

Sebagian informan mengungkapkan sudah mengetahui jenis-jenis APD dan cara menggunakannya. Dari studi dokumentasi, didapatkan juga bahwa SPO untuk pemakaian APD di masing-masing instalasi/ruangan sudah ada. Hanya saja, dari hasil observasi hanya dua dari enam perawat menggunakan APD secara baik dan benar. Penggunaan sarung tangan di ruang rawat inap kadang kala belum digunakan per pasien per tindakan, padahal ketersediaan APD menurut masing- masing kepala ruangan di setiap instalasi selalui ada dan 
memenuhi.

"Kalau penyediaan APD di poliklinik selalu tersedia.. kami selalu dikasi 2 kotak.. itu habis dalam waktu 3 hari.. selalu saya ambil di apotik.. masker juga tidak pernah kosong..." (Informan 3).

Masloman, Kondou dan Tilaar (2015) yang menyatakan bahwa salah satu faktor yang memengaruhi petugas kesehatan dalam menggunakan APD dalam menjamin keselamatannya sebelum bersentuhan dengan pasien dan melakukan tindakan dapat dipengaruhi oleh ketersediaan APD tersebut. Wilma (2013) juga yang menyatakan bahwa semakin baik dukungan manajemen dalam menyediakan sarana dan prasarana penunjang maka pelaksanaan pencegahan infeksi yang dilakukan oleh perawat pelaksana menjadi semakin baik pula.

Menurut asumsi peneliti, hal ini disebabkan karena masih adanya rasa ketakutan perawat dalam menggunakan sumber daya rumah sakit. Perawat takut merugikan rumah sakit apabila menggunakan APD yang banyak. Ketakutan tersebut muncul akibat peraturan sebelumnya yang membatasi pemakaian APD dan mengharuskan perawat ganti rugi apabila APD yang digunakan tidak sesuai ketentuan. Hal ini terlihat dalam pernyataan berikut:

"Handscoen dipakai saat melakukan injeksi dan mengganti perban.. tapi ga selalu dipake soalnya kan boros..." (Informan 1). "Setiap menginjeksi tidak ganti sarung tangan karena biar menghemat..." (Informan 2). "Handscoen sebenarnya selalu tersedia di masingmasing kamar, cuman kami masih takut untuk pemakaiannya..." (Informan 6). "Waktu bayi BAB tidak selalu (pakai handscoen).. karena klo kita hitung-hitung bisa habis dong 1 kotak sarung tangan itu..." (Informan 4).
Beberapa hambatan lain adalah, perawat merasa tidak nyaman terhadap APD yang disediakan, terutama sarung tangan. Perawat mengeluh sarung tangan yang disediakan terlalu tipis dan gampang robek. Kemudian, ukuran sarung tangan yang disediakan juga tidak konsisten, kadang terlalu kecil kadang terlalu besar, sehingga perawat merasa kesulitan saat melakukan tindakan.

\section{Menggunakan Teknik Aseptik}

Sebagian besar informan menyatakan masih kurang baik dalam menggunakan teknik aseptik, baik dari segi cara maupun tahapan-tahapannya. Pemahaman perawat akan teknik aseptik masih sangat minim. Kondisi di atas juga memprihatinkan karena menurut Darmadi (2008), jumlah perawat yang memiliki kemampuan dalam menjalankan dan mempraktikkan teknik aseptik merupakan salah satu faktor standar asuhan keperawatan yang memengaruhi risiko terinfeksi nosokomial.

Perawat yang memiliki kemampuan yang tergolong baik dalam melakukan teknik aseptik yaitu perawat di ruang bedah. Menurut asumsi penulis, kondisi ini terjadi karena lingkungan kerja yang banyak melakukan tindakan perawatan luka akan menunjang kemampuan perawat dalam melaksanakan teknik aseptik menjadi lebih baik, sebaliknya kondisi lingkungan kerja yang jarang melakukan tindak aseptik akan menghambat kemampuan perawat. Ini sejalan dengan Elhinne (2010) yang menyatakan bahwa kemampuan perawat juga dipengaruhi oleh perannya di tempat tugas.

Berdasarkan hasil studi dokumen, ternyata dokumen SPO terkait tindakan aseptik, seperti SPO pemasangan infus, SPO pemasangan kateter, dan SPO penyuntikkan yang aman telah disusun dan tersedia di masing-masing 
bagian/instalasi. Namun, sosialisasi terhadap penerapan SPO tersebut belum maksimal. SPO disusun dalam bentuk buku yang terjilid rapi dan hanya disimpan sebagai bagian dari arsip sehingga belum digunakan sebagaimana mestinya. Para manajer keperawatan RSMP belum meninjau kembali fungsi SPO yang ada di tiap ruangan dan agar setiap perawat pelaksana senantiasa bekerja sesuai SPO yang telah ditetapkan.

\section{Melapor kepada Dokter Jika Ada Tanda dan Gejala Infeksi}

Hampir semua informan yang diwawancarai mengungkapkan bahwa kepatuhan dalam melapor kepada dokter jika ada tanda dan gejala infeksi tergolong baik, hanya terdapat satu perawat yang belum mampu menjelaskan prosedur pelaporan kepada dokter jika ada tanda dan gejala infeksi nosokimial. Perawat tersebut adalah perawat yang tidak pernah mengikuti pelatihan/sosialisasi PPI di rumah sakit.

Menurut Salawati, Herry dan Putra (2014), terdapat hubungan yang signifikan antara pelatihan dengan tindakan perawat dalam pengendalian infeksi nosokomial. Walaupun bertentangan dengan Herpan (2012) yang menyatakan bahwa tidak ada hubungan yang bermakna antara pelatihan dengan kinerja perawat dalam pengendalian infeksi nosokomial, namun Maryati (2011) dalam penelitiannya tentang keefektifan peningkatan kemampuan perawat dalam PPI juga menjelaskan bahwa pelatihan PPI efektif dapat meningkatkan kemampuan praktik perawat dalam melakukan pencegahan infeksi nosokomial.

Pelatihan PPI sebagai investasi rumah sakit bagi perawat untuk terus dapat meningkatkan kemampuannya dalam pencegahan infeksi nosokomial. Wilma (2013) mengemukan bahwa pelatihan merupakan proses mengajarkan pengetahuan dan keahlian tertentu agar karyawan semakin terampil dan mampu dalam melaksanakan tanggung jawabnya dengan semakin baik sesuai dengan standar. Sehingga, pelatihan merupakan salah satu upaya untuk meningkatkan kompetensi individu. Individu yang kompeten memiliki kemampuan yang memadai dalam melakukan pekerjaannya.

Akan tetapi, dari hasil observasi didapati hanya 4 dari 6 perawat yang melapor kepada dokter jika ditemukan tanda dan gejala infeksi nosokomial. Beberapa kendala lainnya seperti dokter yang tiba-tiba berhalangan hadir dan sulit untuk dihubungi terutama di hari libur. Menurut asumsi peneliti, kondisi ini dapat terjadi karena masih kurangnya komitmen kerja para tenaga medis. Pengawasan dari bagian sub etika dan disiplin komite medis belum sepenuhnya berjalan karena masih lemahnya pelaporan. Perawat cenderung segan dan takut melapor setiap penyimpangan yang dilakukan oleh tenaga medis.

\section{Melakukan Isolasi terhadap Pasien dengan Penyakit Menular}

Sebagian informan mengungkapkan masih kurang baik dalam melakukan isolasi khususnya pasien dengan penyakit menular,, terutama untuk menetapkan kategori pasien dengan penyakit menular yang perlu diisolasi. Pengetahuan perawat akan prosedur isolasi terhadap penyakit menular juga masih kurang.

Penelitian Herpan pada tahun 2012 menunjukkaan bahwa responden dengan tingkat pengetahuan rendah berpeluang untuk tidak mengendalikan infeksi nosokomial sebesar 7,115 kali. Hal ini sejalan dengan Zulkifli, Nontji dan Hadju (2014) yang juga menyatakan bahwa terdapat hubungan yang bermakna antara pengetahuan dengan penerapan pencegahan infeksi nosokomial oleh 
perawat pelaksana, sehingga manajemen rumah sakit hendaknya meningkatkan pengetahuan perawat dalam PPI.

Menurut penuturan IPCN kondisi ini terjadi karena sosialisasi belum dilakukan untuk seluruh perawat.

"Isolasi belum disosialisasikan karena kamar itu belum sesuai dengan standar. Ke depannya pengadaan kamar isolasi sesuai standar menjadi program kita..." (Informan 7).

Selain kamar isolasi yang belum sesuai standar, hambatan lain adalah terbatasnya ruang isolasi yang ada di ruangan rawat inap. Disamping itu, masker khusus dan gaun (baju pelindung) untuk kamar isolasi juga belum lengkap tersedia.

Menurut Depkes (2008), agar perawat pelaksana dapat bekerja secara maksimal pimpinan harus bertanggung jawab atas penyediaan serta pemeliharaan sarana klinis dan non klinis yang dibutuhkan untuk pelaksanaan kewaspadaan umum, termasuk fasilitas kamar isolasi. Selain hal tersbut, hambatan juga datang dari segi pasien dan pengunjung yang terkadang menolak memakai APD seperti masker dengan alasan sesak; sandal, gaun dan topi dengan alasan merepotkan dan risih.

\section{Membatasi Paparan Pasien terhadap Infeksi yang Berasal dari Pengunjung}

Sebagian besar informan pada umumnya menunjukan kepatuhan yang baik dalam membatasi paparan pasien terhadap infeksi yang berasal dari pengunjung. Namun, masih terdapat perawat yang hanya mengganggap bahwa cara mencegah paparan infeksi dari pengunjung hanya dilakukan dengan membatasi jumlah pengunjung dan jam berkunjung. Padahal, hal penting lainnya adalah edukasi terhadap pengunjung. Pemberian edukasi kepada pengunjung seperti cara mencuci tangan tidak sempat dilakukan akibat kesibukan perawat dalam melayani pasien.

Cimiotti (2012) menyimpulkan bahwa pengurangan beban kerja perawat merupakan strategi yang menjanjikan untuk membantu mengontrol kejadian infeksi pada fasilitas perawatan akut. Selain itu, hasil penelitian Shang, Stone, dan Larson (2015) juga menunjukkan bahwa jumlah tenaga perawat berkaitan dengan peningkatan resiko infeksi nosokomial. Sehingga, untuk mendapatkan asuhan keperawatan yang profesional, diperlukan adanya ketenagaan/personalia yang memiliki kemampuan dan memadai pula jumlahnya.

Hambatan lain dalam pelaksanaannya, kadang kala terbentur pada budaya masyarakat setempat yang masih mengharuskan pasien harus dijenguk secara beramai-ramai ketika sakit. Selain itu, pengunjung juga kadang kala menolak edukasi yang diberikan oleh perawat. Perbedaan budaya menjadi hambatan terbesar yang dapat menghalangi komunikasi yang paling sulit untuk diatasi terutama apabila penerima juga mempunyai umur, pendidikan, status sosial ekonomi, agama atau kepercayaan, dan pengalaman hidup yang jauh berbeda. Ini sejalan dengan pendapat Fong $\mathrm{Ha}$, Anat dan Longnecker (2010) juga menyatakan bahwa salah satu faktor penghambat dalam pemberian informasi khususnya dalam komunikasi adalah faktor budaya.

\section{Mempertahankan Keamanan Peralatan dan Perlengkapan Perawatan dari Penularan Infeksi Nosokomial}

Sebagian besar informan menunjukan kemampuan yang tergolong kurang baik dalam mempertahankan keamanan peralatan dan perlengkapan perawatan dari penularan infeksi nosocomial. Dari hasil wawancara mendalam, terdapat 
perawat yang belum mengetahui alat- alat yang harus disterilkan dengan cara mengirim ke ruang operasi atau mana saja yang hanya didesinfeksi dengan alkohol swab setelah setiap kali dipakai, begitu juga botol susu di ruang bayi yang harus disterilkan setiap selesai digunakan.

Dari hasil studi dokumen, ternyata dokumen SPO mengenai tata cara mempertahankan keamanan peralatan dan perlengkapan perawatan dari penularan infeksi nosokomial ini telah tersedia di masing-masing instalasi, bahkan telah disosialisasi, namun masih butuh pengarahan. Hal ini dipertegas oleh perawat IPCN yang menyatakan bahwa:

"Menurut saya kemampuannya sedikit kurang.. belum sesuai betul-betul dengan SPO.. perlu disosialisasi ulang dan saya sering keliling... agar bila ada yang tidak sesuai segera diperbaiki..." (Informan 7).

Lama bekerja,dan kesibukan perawat kembali menjadi beberapa kendala dalam pelaksanaannya. Ini terlihat dari pernyataan beberapa informan berikut: "kadang gak sempat kalau stetoskop harus dibersihkan per pasien.. repot aja.. kan harus cuci tangan, bawa status pasien dan lain-lain lagi..." (Informan 2). "Cuman ga setiap kali pakai.. kadang kelupaan hahhaha.. kadang ga sempat..." (Informan 3).

Berdasarkan hasil observasi, setidaknya terdapat 4 perawat yang belum mempertahankan keamanan peralatan dan perlengkapan perawatan dari penularan infeksi nosokomial. Menurut penulis kendala diatas menyebabkan prosedur dalam mensterilkan peralatan dan perlengkapan rumah sakit belum seragam.

Selain itu, adapun hambatan lain yang juga menyulitkan perawat dalam mempertahankan keamanan peralatan dan perlengkapan perawatan dari penularan infeksi nosokomial ialah keterbatasan jumlah cadangan peralatan dan perlengkapan. Hal ini terjadi pada kondisi dimana pasien sangat ramai di suatu instalasi/ruangan di waktu tertentu.

\section{KESIMPULAN}

Untuk delapan area kepatuhan perawat dalam pencegahan dan pengendalian infeksi nosokomial di RSMP diketahui bahwa:

1. Sebagian besar informan menyatakan bahwa perawat sudah baik dalam menjaga kebersihan rumah sakit, namun dari hasil observasi ternyata hanya sebagian kecil perawat yang melakukannya dengan maksimal.

2. Sebagian besar informan mengungkapkan bahwa perawat sudah baik dalam melaksanakan cuci tangan, namun dari hasil observasi hanya sebagian perawat yang mengikuti aturan 6 langkah dan 6 waktu cuci tangan dengan prosedur yang benar.

3. Sebagian informan berpendapat bahwa kepatuhan perawat dalam menggunakan alat pelindung diri sudah tergolong baik, namun dari hasil observasi, ternyata hanya sebagian kecil perawat yang menggunakan APD dengan tepat dan sesuai prosedur.

4. Sebagian besar informan menyatakan bahwa kepatuhan perawat masih kurang baik dalam melakukan teknik aseptik sesuai prosedur, begitu juga dengan hasil observasi

5. Dalam melapor kepada dokter jika ada tanda dan gejala infeksi, hampir semua informan menegaskan bahwa perawat pada umumnya sudah baik. Walaupun 'hasil observasi menemukan masih ada perawat yang belumn melapor kepada dokter sesuai prosedur.

6. Berdasarkan hasil wawancara mendalam dan hasil observasi, sebagian perawat masih kurang baik 
dalam melakukan isolasi terhadap pasien dengan penyakit menular

7. Sebagian besar informan mengungkapkan bahwa kepatuhan perawat dalam membatasi paparan pasien terhadap infeksi yang berasal dari pengunjung sudah tergolong baik. Namun, dari hasil observasi hanya sebagian kecil perawat yang melakukannya sesuai prosedur.

8. Sebagian besar informan menyatakan bahwa kepatuhan perawat dalam mempertahankan keamanan peralatan dan perlengkapan perawatan dari penularan infeksi nosocomial tergolong baik. Namun, dari hasil observasinya ternyata hanya sebagian kecil perawat yang melakukannya sesuai prosedur.

Adapun determinan kepatuha perawat dalam pencegahan dan pengendalian infeksi nosokomial di RSMP adalah pendidikan perawat, lama bekerja, tempat tugas, keterbatasan SDM, keterbatasan alat pendukung, ketidaknyamanan terhadap fasilitas pendukung yang telah tersedia, pelatihan/sosialisasi, lemahnya monitoring dan evaluasi serta kurangnya koordinasi antar unit.

\section{SARAN}

Rumah Sakit agar segera melakukan pelatihan tentang pencegahan dan pengendalian infeksi nosokomial kepada perawat yang belum pernah mengikuti pelatihan dan penyegaran kembali materi terkait PPI kepada perawat yang telah mengikuti pelatihan secara bertahap. Menyediakan atau menambah fasilitas penunjang pencegahan dan pengendalian infeksi yang dibutuhkan, seperti brush cuci tangan, APD seperti celemek dan topi, dan pengadaan kamar/ruang isolasi di Irna, plastik pelapis tong sampah. Untuk jeregen benda tajam sebaiknya ditambah di trolley tindakan pada masing-masing nurse station.

Manajemen rumah sakit dan Tim PPI disarankan untuk mengadakan monitoring dan evaluasi pencegahan dan pengendalian infeksi di semua unit perawatan untuk mengoptimalkan pelaksanaan PPI di rumah sakit.

\section{DAFTAR PUSTAKA}

1. Asmadi. (2008). Konsep Dasar Keperawatan. Jakarta : EGC.

2. Centers for Disease Control and Prevention. (2011). HealthcareAssociated Infection Data and Statistics. Diunduh tanggal 20 Juli 2018. Tersedia dari : http://www.cdc.gov/hai/surveillance/

3. Cimiotti, J.P. (2012). Nurse staffing,Burnout, and Health CareAssociated Infection. Diunduh tanggal 22 Juli 2018. Tersedia dari: http://www.ajicjournal.org/article/S019 6-6553(12)00709-2/abstract

4. Darmadi. (2008). Infeksi Nosokomial Problematika dan Pengendaliannya. Jakarta : Salemba Medika.

5. Departemen Kesehatan Republik Indonesia. (2008). Pedoman Pencegahan dan Pengendalian Infeksi di Rumah Sakit dan Fasilitas Pelayanan Kesehatan Lainnya Kesiapan Menghadapi Emerging Infection Disease. Jakarta.

6. Departemen Kesehatan Republik Indonesia. (2008). Pedoman Manajerial Pencegahan dan Pengendalian Infeksi di Rumah Sakit dan Fasilitas Pelayanan Kesehatan Lainnya. Jakarta.

7. Elhinney, M. (2010). Factors Which Influence Nurse Practitioners Ability to Carry Out Physical Examination Skills in the Clinical Area After A Degree Level Module-An Electronic Delphi 
Study. J ClinNurs. 2010 Nov; 19(2122).

8. Fong $\mathrm{Ha} \mathrm{J}$, Anat DS, Longnecker. (2010). Doctor - Patient Communication: A Review. The Ochsner Journal 2010; Volume 10:38 -43 .

9. Herpan, Y. W. (2012). Analisis Kinerja Perawat dalam Pengendalian Infeksi Nosokomial di RSU PKU Muhammadiyah Bantul Yogyakarta. KES MAS Vol. 6, No. 3, September 2012 : 144-211.

10. Mathuridy, R. M. (2015). Hubungan Umur, Lama Kerja, Pendidikan dan Motivasi dengan Kepatuhan Perawat Melakukan Enam Langkah Lima Momen Cuci Tangan di Ruang ICU RSUD Ulin Banjarmasin. Caring, Vol.3, No.2, September 2015.

11. Maryati, S. (2012). Keefektifan Peningkatan Kemampuan Perawat Dalam Pencegahan Infeksi Nosokomial Pada Bayi Di Ruang Neonatal Intensive Care Unit Rumah Sakit Umum Daerah Wates Kulon Progo. Jurnal Kesehatan Samodra Ilmu (Jurnal Stikes Yogyakarta), Vol.3, No.1, 2012

12. Masloman, A. P, G. D Kondou dan Ch. R. Tilaar. (2015). Analisis Pelaksanaan Pencegahan dan Pengendalian Infeksi di Kamar Operasi RSUD Dr Sam Ratulangi Tondano. JIKMU, Vol.5, No.2, April 2015.

13. Mulyatiningsih, S. (2013). Determinan Perilaku Perawat dalam Melaksanakan Keselamatan Pasien di Rawat Inap DR.Esnawan Antariksa Jakarta. Diunduh pada tanggal 2 Juni 2016. Tersedia dari: http://lib.ui.ac.id/file?file=digital/20334 194-T32569-

Sri\%20Mulyatiningsih.pdf
14. Nugraheni, dkk. (2012). Infeksi Nosokomial di RSUD Setjonegoro Kabupaten Wonosobo. Media Kesehatan Masyarakat Indonesia, Vol. 11 / No.1, April 2012.

15. Peraturan Menteri Kesehatan Republik Indonesia Nomor 27 Tahun 2017 Tentang Pedoman Pencegahan Dan Pengendalian Infeksi Di Fasilitas Pelayanan Kesehatan

16. Pristiwani. (2013).Peran Perawat dalam Pengendalian Infeksi Nosokomial di Rumah Sakit Umum Daerah Dr. T. Mansyur Tanjung Balai. Program Studi IImu Keperawatan Fakultas Keperawatan Universitas Sumatera Utara.

17. RSMP. (2017). Profil Rumah Sakit Tahun 2015. Palembang.

18. Salawati, L, Herry, N. dan Putra, A. (2014). Analisis Tindakan Keselamatan dan Kesehatan Kerja Perawat Dalam Pengendalian Infeksi Nosokomial Di Ruang ICU RSUD DR. Zainoel Banda Aceh. JURNAL KEDOKTERAN SYIAH KUALA Volume 14 Nomor 3 Desember 2014.

19. Saragih, R dan Rumpea, N. (2010). Hubungan Karakteristik Perawat dengan Tingkat Kepatuhan Perawat Melakukan Cuci Tangan di Rumah Sakit Columbia Asia Medan. Diunduh pada tanggal 2 Juli 2018. Tersedia dari: http://uda.ac.id/jurnal/files/7.pdf

20. Shang, J., Stone, P., dan Larson, E. (2015). Studies on nurse staffing and health care- associated infection : Methodologic challenges and potential solutions. American Journal of Unfection Control Volume 43, Issue 6. Pages 581-588.

21. Sugiyono. (2015). Metode Penelitian Pendidikan-Pendekatan Kuantitatif, Kualitatif, dan R\&D, Cetakan ke 21, Penerbit Alfabeta, Bandung. 
22. Undang-Undang Republik Indonesia Nomor 44 Tahun 2009 Tentang Rumah Sakit

23. Wilma. (2013). Faktor-Faktor yang Berhubungan dengan Pelaksanaan Pencegahan Infeksi Nosokomial oleh Perawat Pelaksana di Rumah Sakit Umum Daerah Makasar Tahun 2013. Dinduh tanggal 3 Juli 2016. Tersediadari:

http://repository.unhas.ac.id:4001/digil ib/files/disk1/53/--wilma-2602-1-13wilma-8.pdf

24. World Health Organization (WHO). (2010). The Burden of HealthcareAssociated Infection Worldwide. Diunduh tanggal 20 Februari 2016. Tersedia dari: http://www.who.int

25. World Health Organization (WHO). (2010). Infeksi Nosokomial dan Kewaspadaan Universal. Diunduh pada tanggal 20 Februari 2016. Tersedia dari: http://spiritia.or.id

26. World Health Organization (WHO). (2002). Prevention of HospitalAcquired Infections A Practical Guide 2nd Edition. Departement of Communicable Disease, Surveilance and Response. Diunduh tanggal 4 Februari 2016. Tersedia dari: http://www.who.int

27. Zulkifli, Nontji,W., dan Hadju, V. (2014). Faktor Determinan dan Tanggung Jawab Perawat Terhadap Penerapan Pencegahan dan Pengendalian Infeksi Nosokomial. Diunduh tanggal 2 Juni 2016. Tersedia dari: http://repository.unhas.ac.id:4001/digil ib/files/disk1/339/--zulkifliwe-16935- 1jurnalz-).pdf 